PIWULANG: Jurnal Pendidikan Agama Islam, Vol. 3 No. 1 September 2020, 56-64

P-ISSN : 2622-5638. E-ISSN : 2622-5654

Homepage: http://e-journal.staima-alhikam.ac.id/index.php/piwulang

\title{
PEMBELAJARAN PAI KONTEKSTUAL DI SMP AR-RAHMAT BOJONEGORO
}

\author{
MUTAMAKIN \\ STAI Ma'had 'Aly Al-Hikam Malang - INDONESIA \\ Email: mt.makkin@gmail.com
}

\begin{abstract}
This research focuses on the implementation of contextual Islamic Education learning at SMP Al-Rahmat Bojonegoro. The results of this study indicate: 1) The paradigm shift of Islamic Education teachers from the conventional paradigm (students as objects), to the new paradigm of students as learning subjects. Teachers have an understanding that learners' knowledge always develops according to experience; 2) Contextual learning activities are carried out in a conducive learning atmosphere, the assessment is carried out as a whole; cognitive, affective and psychomotor. 3) Students have a good response to this contextual learning. With the perception and understanding of the importance of contextual learning from teachers, plus a positive response from students, the implementation of contextual Islamic Education learning can increase students' motivation to learn and improve learning outcomes and provide students with social life skills.
\end{abstract}

\section{Abstrak}

Fokus Penelitian ini adalah pelaksanaan pembelajaran PAI kontekstual di SMP Al-Rahmat Bojonegoro. Hasil dari penelitian ini menunjukkan: 1) Perubahan paradigma Guru PAI dari paradigma konvensional (peserta didik sebagai objek), kepada paradigma baru peserta didik sebagai subyek belajar. Guru memiliki pemahaman bahwa pengetahuan peserta didik selalu berkembang sesuai dengan pengalaman; 2) Kegiatan pembelajaran kontekstual dilaksanakan dengan suasana pembelajaran yang kondusif, penilaian dilakukan secara menyeluruh; kognitif, afektif dan psikomotor. 3) Peserta didik memiliki respon yang baik terhadap pembelajaran kontekstual ini. Dengan adanya persepsi dan pemahaman pentingnya pembelajaran kontekstual dari para guru, ditambah respon positif dari peserta didik, implementasi pembelajaran PAI kontekstual dapat meningkatkan motivasi belajar peserta didik dan meningkatkan hasil akhir belajar serta memberi bekal peserta didik dengan sosial life skill.

Kata Kunci : Pembelajaran PAI Kontekstual, SMP 
PIWULANG: Jurnal Pendidikan Agama Islam, Vol. 3 No. 1 September 2020, 56-64

P-ISSN : 2622-5638. E-ISSN : 2622-5654

Homepage: http://e-journal.staima-alhikam.ac.id/index.php/piwulang

\section{A. Pendahuluan}

Pendidikan Agama Islam di sekolah memiliki tugas penting dalam penanaman keimanan dan ketaqwaan serta pembentukan akhlak mulia, yang diharapkan menjadi pedoman untuk meraih kebahagian hidup di dunia dan di akhirat. Selain itu Pendidikan Agama Islam juga turut membentuk mental peserta didik untuk beradaptasi dengan lingkungan fisik dan sosial. ${ }^{1}$

Di sisi lain, pembinaan Pendidikan Agama Islam perlu dikembangkan melalui kerjasama terpadu antara fihak sekolah dan masyarakat. Untuk itu guru Pendidikan Agama Islam dituntut berperan aktif memantau kegiatan Pendidikan Agama Islam yang diperoleh peserta didik lingkungannya (keluarga dan masyarakat), agar terwujud keselarasan dan kesesuaian sikap serta perilaku antara pembinaan di sekolah dengan di masyarakat. Sebagai konsekuensi, guru Pendidikan Agama Islam selalu dituntut untuk melakukan inovasi dan kreatifitas pembelajaran. Salah satu inovasi pembelajaran adalah model pembelajaran kontekstual.

Kegiatan pembelajaran bukan lagi sekedar kegiatan mengajar yang hanya menyiapkan dan melaksanakan prosedur pembelajaran. Kegiatan pembelajaran dalam realitanya lebih kompleks lagi dan harus dilaksanakan dengan pola-pola pembelajaran yang variatif. ${ }^{2}$

Hingga saat ini pembelajaran Pendidikan Agama Islam masih dihadapkan pada beberapa persoalan fundamental, antara lain: 1) pendekatan pembelajaran PAI yang masih normatif dan teoritis, sehingga kurang menyentuh pada nilai kehidupan sehari-hari (kontekstual), 2) minimnya kreatifitas guru dalam upaya pengayaan kurikulum, dan dalam penggunaan metode pembelajaran, sehingga proses pembelajaran dilakukan secara menoton, 3) sarana dan prasarana Pendidikan Agama Islam yang kurang mendukung, dan 4) dampak politik pendidikan sentralistik. $^{3}$

Selain itu, pembelajaran Pendidikan Agama Islam juga masih berhadapan dengan beberapa problem internal, yaitu antara lain; (1) Pendidikan Agama Islam belum mampu mengembangkan pengetahuan

\footnotetext{
${ }^{1}$ Muhaimin, et.al. 2002. Paradigma Pendidikan Islam Upaya Mengefektifkan Pendidikan Agama Islam di Sekolah. Bandung: Rosdakarya. Hlm. 77

${ }^{2}$ Toto Ruhimat, 2011. Kurikulum dan Pembelajaran. Jakarta: Rajawali Press. Hlm. 120

${ }^{3}$ Cahirul Fuad Yusuf. 2007. Inovasi Pembelajaran Pendidikan Agama Islam (SMP). Jakarta: Pena Citarasa. HIm. 22
} 
PIWULANG: Jurnal Pendidikan Agama Islam, Vol. 3 No. 1 September 2020, 56-64

P-ISSN : 2622-5638. E-ISSN : 2622-5654

Homepage: http://e-journal.staima-alhikam.ac.id/index.php/piwulang

agama kognitif menjadi makna dan nilai yang terinternalisasi dalam diri peserta didik. Secara umum, Pendidikan Agama Islam lebih menekankan pada aspek knowing dan having religion, dan belum mengarah ke aspek being religious, (2) Pendidikan Agama Islam belum mampu bersinergi dengan program-program pendidikan non-keagamaan, (3) Pendidikan Agama Islam yang diajarkan kurang mempunyai relevansi terhadap perubahan sosial yang terjadi di masyarakat, sehingga peserta didik kurang menghayati nilai-nilai agama sebagai prinsip yang memandu kehidupannya. ${ }^{4}$

Penelitian ini dilaksanakan di SMP Ar-Rahmat Bojonegoro, Jawa Timur. Berdasarkan survey awal, SMP Ar-Rahmat Bojonegoro merupakan sekolah yang berkualitas dan dilengkapi dengan sarana dan prasarana pembelajaran yang sangat memadai untuk mendukung pembelajaran Pendidikan Agama Islam. Minat masyarakat untuk memasukkan putranya ke sekolah ini sangat tinggi, karena sekolah ini dikenal sekolah swasta unggul dan favorit, bahkan mampu bersaing dengan sekolah milik pemerintah. Sejak tiga tahun awal berdiri, sekolah ini telah meraih prestasi tingkat regional dan nasional. Dari data pendaftaran calon peserta didik, input di SMP Ar-Rahmat Bojonegoro cukup bagus, dari statistik menunjukkan peningkatan peserta didik tiap tahun. Bahkan SMP ArRahmat Bojonegoro menjadi prioritas destinasi sekolah favorit se karesidenan Bojonegoro (meliputi Bojonegoro, Tuban, Lamongan).

Penelitian di SMP Ar-Rahmat ini akan difokuskan pada tiga hal, pertama, bagaimana persepsi guru PAI di SMP Ar-Rahmat Bojonegoro tentang model pembelajaran kontekstual. Kedua, bagaimana kegiatan model pembelajaran kontekstual pada mata pelajaran PAI dan Ketiga, bagaimana respon peserta didik di SMP Al-Rahmat Bojonegoro terhadap implementasi pembelajaran kontekstual pada mata pelajaran PAI.

\section{B. METODE PENELITIAN}

Penelitian ini menggunakan pendekatan kualitatif (qualitative approach). Bogdan dan Taylor (2016) mendefinisikan bahwa pendekatan kualitatif merupakan penelitian yang menghasilkan data deskriptif berupa kata-kata tertulis atau lisan dari orang-orang dan perilaku yang dapat

\footnotetext{
${ }^{4}$ Muhaimin. 2009. Rekonstruksi Pendidikan Islam dari Paradigma Pengembangan, Manajemen Kelembagaan, Kurikulum hingga Strategi Pembelajaran. Jakarta: PT RajaGrafindo Persada. HIm. 58
} 
PIWULANG: Jurnal Pendidikan Agama Islam, Vol. 3 No. 1 September 2020, 56-64

P-ISSN : 2622-5638. E-ISSN : 2622-5654

Homepage: http://e-journal.staima-alhikam.ac.id/index.php/piwulang

diamati. ${ }^{5}$ Jenis penelitian yang digunakan adalah analisis diskriptif. Penelitian ini mengambil lokasi di SMP Ar-Rahmat Bojonegoro .

Sumber data dalam penelitian ini adalah kepala sekolah, guru PAI, dan peserta didik di SMP Ar-Rahmat Bojonegoro. Data yang diperoleh dirumuskan dalam bentuk transkip wawancara dan catatan pengamatan lapangan. Sedangkan data lain diperoleh melalui analisis dokumen.

Pengumpulan data dalam penelitian ini menggunakan metode wawancara, observasi, dan analisis dokumen. Wawancara dilakukan untuk memperoleh dan menggali data terkait kegiatan pembelajaran kontekstual mapel PAI, yang meliputi persepsi guru dan respon dari peserta didik. Observasi dilakukan untuk mengetahui sejauh mana pelaksanaan kegiatan pembelajaran kontekstual mapel PAI. Selanjutnya dilakukan analisis dokumen pembelajaran dan dokumen lain yang terkait dengan penelitian ini.

Dalam penelitian ini analisis data yang digunakan adalah analisis non statistik yang terhimpun dalam transkrip data wawancara, observasi serta dokumen. Tahapan langkah analisis penelitian ini adalah: (1) reduksi data, (2) display data, (3) pengambilan simpulan dan verifikasi. Untuk verifikasi keabsahan data, peneliti melaksanakan penelitian ini dalam kurun waktu satu semester dan dilakukan secara kontinyu. Data yang telah diperoleh kemudian dikomunikasikan dengan beberapa fihak untuk memastikan keabsahannya.

\section{Hasil Penelitian dan Pembahasan}

1. Persepsi guru PAI tentang Pembelajaran Kontekstual

Dari hasil observasi dan wawancara menunjukkan bahwa Guru PAI di SMP Al-Rahmat Bojonegoro sudah sangat memahami dan familiar dengan pembelajaran kontekstual. Dalam pandangan mereka, pembelajaran kontekstual dapat membantu guru mengintegrasikan materi PAI dengan konteks kehidupan nyata peserta didik. Dengan pembelajaran kontekstual ini peserta didik dilatih untuk mampu memahami materi yang diajarkan dan mampu menunjukkan penerapannya dalam kehidupan dalam keluarga dan masyarakat. Model pembelajaran kontekstual merupakan sebuah sistem pembelajaran yang merangsang otak peserta didik untuk memahami makna. Selanjutnya

\footnotetext{
${ }^{5}$ Steven J. Taylor \& Robert Bogdan, Introduction to Qualitative Research Methods, 4th Edition, (John Wiley \& Sons, Inc., Hoboken, New Jersey, 2016)
} 
PIWULANG: Jurnal Pendidikan Agama Islam, Vol. 3 No. 1 September 2020, 56-64

P-ISSN : 2622-5638. E-ISSN : 2622-5654

Homepage: http://e-journal.staima-alhikam.ac.id/index.php/piwulang

peserta didik diarahkan untuk menghubungkan pengetahuan kognitif dengan konteks kehidupan real. Konteks di sini difahami sebagai lingkungan dunia luar yang dikomunikasikan melalui pancaindera dan ruang waktu kehidupan sehari-hari. (wawancara guru PAI).

Menurut Kepala Sekolah SMP Al-Rahmat, persepsi guru PAI tentang pembelajaran kontekstual sangat bagus. Dalam pengamatan kepala sekolah, kegiatan pembelajaran yang dilakukan oleh guru PAI cukup inovatif dan kreatif, kemampuan ini menurut kepala sekolah berkaitan dengan persepsi dan pemahaman mereka. (wawancara kepala sekolah)

Dalam pembelajaran kontekstual ini guru PAI di SMP Ar-Rahmat Bojonegoro memberi fasilitas kegiatan belajar kepada peserta didik untuk mencari, mengolah, dan menemukan pengalaman belajar yang lebih konkret (kehidupan nyata) melalui aktivitas pengalaman langsung.

Guru PAI di SMP Al-Rahmat Bojonegoro memandang pembelajaran kontekstual dapat memberi bekal peserta didik berupa pengetahuan dan life skill yang realistis. Bagi guru, pembelajaran kontekstual ini sangat membantu untuk menghubungkan materi yang diajarkan dengan kehidupan nyata sehingga peserta didik dapat mengaplikasikan dalam kehidupannya di keluarga maupun masyarakat.

Persepsi guru sebenarnya berhubungan dengan kompetensi pedagogiknya. Kompetensi pedagogik sebagai salah satu kompetensi yang perlu dimiliki oleh guru, perlu dikembangkan dan ditingkatkan. Pengembangan kompetensi guru, termasuk guru PAI di SMP Ar-Rahmat Bojonegoro dilakukan dengan beberapa program. Di antara program ini adalah dengan menumbuhkan kesadaran diri para guru untuk terusmenerus melakukan inovasi pembelajaran. Selain itu para guru dimotivasi untuk aktif mengikuti kegiatan pelatihan-pelatihan peningkatan kompetensi pedagogik dan studi lanjut pada jenjang pendidikan yang lebih tinggi.

Dari uraian di atas, dapat diketahui dengan jelas bahwa persepsi guru PAI di SMP Ar-Rahmat Bojonegoro memiliki pemahaman dan persepsi yang bagus terhadap pembelajaran kontekstual. Dalam survei yang dilaksanakan terhadap guru PAI di SMP Ar-Rahmat ditemukan bahwa;

a) Peserta didik dipandang sebagai subyek belajar, artinya peserta didik diberi peran aktif dalam proses pembelajaran melalui kemandirian belajar peserta didik, 
PIWULANG: Jurnal Pendidikan Agama Islam, Vol. 3 No. 1 September 2020, 56-64

P-ISSN : 2622-5638. E-ISSN : 2622-5654

Homepage: http://e-journal.staima-alhikam.ac.id/index.php/piwulang

b) Dalam pembelajaraan, peserta didik dibagi dalam beberapa kelompok untuk meningkatkan kemampuan teamwork,

c) Materi pelajaran PAI dikembangkan sesuai dengan konteks kehidupan sehari-hari peserta didik,

d) Guru PAI berperan sebagai pendamping dan fasilitator,

e) Guru melakukan evaluasi dan penilaian secara objektif meliputi pengetahuan, sikap, dan keterampilan.

2. Kegiatan Pembelajaran PAI Kontekstual di SMP Al-Rahmat Bojonegoro

Kegiatan pembelajaran kontekstual yang dilaksanakan di SMP Arrahmat Bojonegoro di antaranya adalah: perencanaan pembelajaran dengan menjabarkan kompetensi dasar serta indikatornya, penentuan kedalaman dan keluasan materi pembelajaran, penyampaian materi secara kontekstual dengan metode yang variatif, penentuan evaluasi dan penilaian dengan tes tulis, tes kinerja, dan portofolio.

Dalam kegiatan pembelajaran kontekstual ini, langkah- langkah pembelajaran yang dilakukan adalah;

a) Menjelaskan kompetensi. Penjelasan kompetensi ini meliputi capaian dan manfaat dari proses pembelajaran dan urgensi materi pelajaran.

b) Membentuk kelompok. Peserta didik membentuk kelompok kecil, tiap-tiap kelompok diberi tugas sesuai dengan pokok-pokok bahasan.

c) Masing-masing kelompok peserta didik mengamati dan mencatat realitas sosial secara langsung atau melalui media pembelajaran yang digunakan, seperti penggunaan audio visual dan lembar catatatan.

d) Hasil catatan yang diperoleh tiap kelompok, kemudian didiskusikan selanjutnya dilakukan sharing bersama.

e) Guru mendampingi dan memberikan arahan serta memberikan ulasan lesson learneada terhadap materi yang telah didiskusikan.

f) Di akhir pembelajaran, Guru memberikan tugas follow up.

Untuk mengukur ketercapain tujuan dalam pembelajaran kontekstual ini, Guru melakukan kegiatan penilaian secara menyeluruh. Penilaian menyeluruh meliputi penilaian terhadap proses dan hasil pembelajaran. Penilaian ini mencakup kesiapan peserta didik, proses, dan hasil belajar peserta didik secara utuh. Penilaian yang dilakukan oleh guru tidak hanya mengukur kemampuan kognitif peserta didik saja, tetapi juga afeksi dan psikomotor peserta didik. (wawancara guru PAI) 
PIWULANG: Jurnal Pendidikan Agama Islam, Vol. 3 No. 1 September 2020, 56-64

P-ISSN : 2622-5638. E-ISSN : 2622-5654

Homepage: http://e-journal.staima-alhikam.ac.id/index.php/piwulang

Langkah-langkah pembelajaran kontekstual yang dilakukan oleh guru PAI di SMP Al-Rahmat Bojonegoro ini sudah memperhatikan dan mendasarkan pada komponen-komponen yang ada pada pembelajaran kontekstual. Komponen-komponen itu adalah (1) konstruktivisme, yaitu pengetahuan dibangun dari diri sendiri yang diperluas berdasarkan pengetahuan dan interaksi sosial, (2) questioning, yaitu guru bertanya dengan menggali informasi tentang apa yang sudah diketahui, (3) inquiry, yaitu pengetahuan dan keterampilan yang diperoleh peserta didik merupakan hasil dari temuan sendiri, (4) learning community, yaitu belajar merupakan sharing, saling memberi informasi, (5) modelling, yaitu guru mengarahkan peserta didik untuk mendemonstrasikan pengetahuan dan keterampilannya, (6) reflection, yaitu pemahaman terhadap makna dari kegiatan atau pengetahuan, dan (7) autentic assessment, yaitu guru menggunakan penilaian yang menyeluruh mencakup pengetahuan, sikap, dan psikomotor.

3. Respon Peserta Didik terhadap Pembelajaran Kontekstual pada Mata Pelajaran PAI di SMP Al-Rahmat Bojonegoro

Dari hasil observasi dan wawancara kepada peserta didik di SMP ArRahmat diketahui bahwa respon peserta didik terhadap pembelajaran kontekstual mata pelajaran PAI di SMP Ar-Rahmat Bojonegoro, cukup positif dan bagus. Hal ini tampak dari antusiasme dan semangat belajar serta perhatian peserta didik selama mengikuti proses pembelajaran, indikator lain tampak dari hasil belajar peserta didik di atas nilai KKM. Kompetensi sikap yang dicapai oleh peserta didik, tampak cukup baik, misalnya; sikap ketika menyampaikan ide dan pikiran, ketika menyampaikan usul dan saran dalam diskusi kelompok, peserta didik mampu menghargai pendapat orang lain, tugas dan tanggung jawab dalam kelompok dilaksanakan dengan baik, kerja sama dalam tim cukup baik. (wawancara guru PAI). Secara umum, keterlibatan peserta didik selama proses pembelajaran cukup aktif.

Menanggapi hasil pembelajaran kontekstual ini, kepala sekolah menyatakan bahwa kompetensi peserta didik dari aspek sikap spiritual dan sosial cukup baik, seperti; disiplin, tanggung jawab, toleransi, menghargai senior dan guru, dan keaktifan mengikuti sholat dhuhur berjamaah di sekolah. melalui pembelajaran kontekstual ini terlihat dapat mengantarkan peserta didik pada tahap afeksi dan psikomotorik. (wawancara kepala sekolah)

Respon yang cukup tinggi dari peserta didik ketika mengikuti pembelajaran PAI dengan pembelajaran kontekstual terlihat dari 
PIWULANG: Jurnal Pendidikan Agama Islam, Vol. 3 No. 1 September 2020, 56-64

P-ISSN : 2622-5638. E-ISSN : 2622-5654

Homepage: http://e-journal.staima-alhikam.ac.id/index.php/piwulang

motivasi yang tinggi untuk mengikuti aktivitas belajar. Motivasi belajar merupakan kunci untuk menggerakkan aktifitas belajar yang lebih lanjut. Dengan tumbuhnya motivasi belajar ini dapat membantu peserta didik menerima dan memahami materi pelajaran. Respon peserta didik dalam mengikuti proses pembelajaranmerupakan salah satu komponen dalam kegiatan penilaian. Penilaian dalam proses pembelajaran meliputi respon, perhatian, keterlibatan, kesungguhan, dan semangat belajar peserta didik serta kesesuaian dengan pembelajaran yang dilaksanakan oleh guru dalam rangka mencapai tujuan pembelajaran.

Penilaian hasil belajar merupakan kegiatan guru yang berkaitan dengan pengambilan keputusan tentang capaian kompetensi hasil belajar peserta didik yang mengikuti proses pembelajaran. Untuk memperoleh data sebagai bahan penilaian, selama pembelajaran berlangsung guru menggunaakan prosedur dan alat penilaian yang sesuai dengan kompetensi atau indikator yang akan dinilai. Hasil dari proses ini akan diperoleh gambaran atau profil sejumlah kompetensi inti dan kompetensi dasar tentang kemampuan peserta didik sebagaimana telah dirumuskan dalam kurikulum.

\section{PENUTUP}

Dari penelitian tentang pembelajaran PAI kontekstual di di SMP ArRahmat Bojonegoro ini diketahui bahwa:

1. Persepsi guru PAI SMP Al-Rahmat Bojonegoro tentang pembelajaran kontekstual cukup bagus. Guru PAI di SMP Ar-Rahmat Bojonegoro memandang bahwa peserta didik adalah subyek belajar, artinya peserta didik harus berperan aktif dalam proses pembelajaran. Guru mempersiapkan materi pelajaran yang dikaitkan dengan konteks kehidupan sehari-hari. Pengetahuan masing-masing peserta didik selalu berkembang sesuai dengan pengalaman di lingkungannya. Guru melakukan penilaian secara obyektif yang meliputi pengetahuan, sikap, dan keterampilan.

2. Pelaksanaan pembelajaran PAI kontekstual yang dilakukan oleh guru di SMP Al-Rahmat Bojonegoro adalah cukup baik dan dinamis. Model pembelajaran kontekstual ini terbukti mampu menciptakan suasana yang kondusif. Guru PAI melakukan penilaian secara menyeluruh, yaitu berorientasi pada capaian kompetensi peserta didik dari aspek kognitif, afektif dan psikomotor. Penilaian yang dilakukan oleh guru ini berorientasi pada input, proses, dan output. 
PIWULANG: Jurnal Pendidikan Agama Islam, Vol. 3 No. 1 September 2020, 56-64 P-ISSN : 2622-5638. E-ISSN : 2622-5654 Homepage: http://e-journal.staima-alhikam.ac.id/index.php/piwulang

3. Pembelajaran PAI kontekstual di SMP Al-Rahmat Bojonegoro ini mendapat respon yang cukup baik dari peserta didik. Indikator respon ini tampak dari meningkatnya motivasi belajar peserta didik dan keaktifan peserta didik selama kegiatan pembelajaran. Hasil akhir dari pembelajaran kontekstual ini terlihat naik secara signifikan dari tingginya nilai rata-rata peserta didik. Sedangkan dari aspek sosial, peserta didik mengalami perubahan sikap yang lebih baik, seperti kedisiplinan, toleransi, tanggung jawab, serta semangat mengamalkan ajaran agama.

\section{DAFTAR PUSTAKA}

Danim, Sudarwan. 2010. Profesionalisasi dan Etika Profesi Guru. Bandung: Alfabeta.

Kunandar. 2014. Penilaian Autentik Suatu Pendekatan Praktis. Jakarta: PT Rajagrafindo Persada.

Muhaimin, et.al. 2002. Paradigma Pendidikan Islam Upaya Mengefektifkan Pendidikan Agama Islam di Sekolah. Bandung: Rosdakarya.

Muhaimin. 2009. Rekonstruksi Pendidikan Islam dari Paradigma Pengembangan, Manajemen Kelembagaan, Kurikulum hingga Strategi Pembelajaran. Jakarta: PT RajaGrafindo Persada.

Ruhimat, Toto. 2011. Kurikulum dan Pembelajaran. Jakarta: Rajawali Press.

Rusman. 2013. Model-Model Pembelajaran Mengembangkan Profesionalisme Guru. Jakarta: Raja Grafindo Persada.

Sanjaya, Wina. 2008. Strategi Pembelajaran Berorientasi Standar Proses Pendidikan. Jakarta: Kencana.

Steven J. Taylor \& Robert Bogdan, Introduction to Qualitative Research Methods, 4th Edition, (John Wiley \& Sons, Inc., Hoboken, New Jersey, 2016)

Yusuf, Cahirul Fuad. 2007. Inovasi Pembelajaran Pendidikan Agama Islam (SMP). Jakarta: Pena Citarasa. 